\title{
Malignant Skin Tumors in Patients with Oculocutaneous Albinism
}

Makiko Yasumizu ${ }^{1}$, Chikako Nishigori ${ }^{2}$, Masakazu Kawaguchi ${ }^{3}$, Tomoya Takata ${ }^{4}$, Naoki Oiso ${ }^{5}$, Tamio Suzuki ${ }^{3}$, Ayano Umekoji ${ }^{1}$, Daisuke Tsuruta ${ }^{1}$ and Kazuyoshi Fukai*1

${ }^{1}$ Department of Dermatology, Graduate School of Medicine, Osaka City University, Osaka, Japan

2Division of Dermatology, Department of Internal Related, Kobe University Graduate School of Medicine, Kobe, Japan

${ }^{3}$ Department of Dermatology, Faculty of Medicine, Yamagata University, Yamagata, Osaka-Sayama, Japan

${ }^{4}$ Department of Dermatology, Kochi University, Kochi, Japan

${ }^{5}$ Department of Dermatology, Faculty of Medicine, Kinki University, Osaka-Sayama, Japan

*Corresponding author: Kazuyoshi Fukai, Department of Dermatology, Graduate School of Medicine, Osaka City University, Osaka, Japan, Tel: +81-6-6645-3826; Fax: +81-6-6645-3828; E-mail: fukai@msic.med.osaka-cu.ac.jp

Rec date: September 25, 2015; Acc date: October 01, 2015; Pub date: October 5, 2015

Copyright: @ 2015 Yasumizu M et al. This is an open-access article distributed under the terms of the Creative Commons Attribution License, which permits unrestricted use, distribution, and reproduction in any medium, provided the original author and source are credited.

\begin{abstract}
Background: Patients with oculocutaneous albinism (OCA) are prone to develop skin cancers.

Aim and Objectives: To analyze reports of skin cancers in albinos published in the English and the Japanese literature in order to prepare guidelines for the successful management of skin cancer in albinos.

Methods and Materials: We searched on PubMed, Web of Knowledge for English literature, and Ichushi-Web for the Japanese literature.

Results: Between 1978 and 2013, 11 malignant melanoma, 4 basal cell carcinoma, and 6 squamous cell carcinoma cases were reported in Japan. The subtypes of the 11 malignant melanomas were nodular in 7 cases, superficial spreading in 3 cases, and metastatic lesions in 1 case. Amelanotic melanomas comprised 7 of the 11 malignant melanoma cases in Japanese patients with OCA. Twenty-five malignant melanoma, 50 basal cell carcinoma, and 151 squamous cell carcinoma cases were reported worldwide in the English literature during the period between 1952 and 2013.
\end{abstract}

Conclusion: Regular skin monitoring by board-certified dermatologists is required for adult OCA patients.

Keywords: Oculocutaneous albinism; Skin cancer; Melanoma; Basal cell carcinoma; Squamous cell carcinoma

\section{Introduction}

Oculocutaneous albinism (OCA) patients are well known to be susceptible to skin cancer. Among 164 northern Tanzanians with OCA, 127 and 69 exhibited actinic cheilitis and actinic keratosis, respectively, and 14 developed squamous cell carcinoma (SCC) [1]. Malignant melanoma (MM) development has been shown to be strongly associated with sun exposure [2]. Recent sequencing analyses revealed that ultraviolet light induces somatic genome alterations that might lead to MM development $[3,4]$.

A 'guideline for the management of Japanese albinos is now being prepared, in which, the significance of sunscreens will be stressed. However, data about the development of skin cancers in Japanese albinos is insufficient. Therefore, we conducted a survey on the occurrence of skin cancers in OCA patients in both the Japanese and English literatures.

\section{Materials and Methods}

We searched the PubMed and Web of Knowledge (version 5.10) databases for English language reports and the Ichushi-Web (version
5) database for Japanese language reports; all publications were available at the end of May 2014.

\section{Results}

In the English literature, $25 \mathrm{MM}$ [5-12] (Table 1), 50 BCC [13-17] (Table 2), and 151 SCC [1,12-14] (Table 3) cases were reported between 1952 and 2013. Most of the reported cases were in African subjects, but Caucasians were included and comprised $6 \mathrm{MM}$ cases and 1 BCC case. We found no reported cases of SCC in Caucasian albinos.

In Japan, 11 MM, 4 BCC, and 6 SCC cases were reported (Tables 4, 5) between 1984 and 2013. The 11 reported MM cases included 7 cases of nodular melanoma, 3 cases of superficial spreading melanoma, and 1 case of metastatic lesions. Amelanotic melanomas occurred in 7 cases. No cases of acral lentiginous melanoma were reported, despite this being the most prevalent MM type in Japan. These numbers are depicted in Figure 1; the occurrence of MM in Japanese OCA patients appears to be substantial.

We summarized a case series of malignant skin tumors in nonAsian individuals and in Japanese persons with OCA. In the Japanese OCA patients, BCCs and SCCs were not common, whereas the incidence of MM was substantial. 


\begin{tabular}{|c|c|c|c|c|}
\hline Author(s) & Year & $\begin{array}{l}\text { No. of } \\
\text { Cases }\end{array}$ & Ethnicity & Ref. No. \\
\hline Bhende & 1952 & 1 & Indian & 47 \\
\hline Young & 1957 & 1 & NR & 48 \\
\hline Leonardi & 1958 & 1 & NR & 49 \\
\hline Higginson & 1960 & 1 & African & 41 \\
\hline Kennedy & 1963 & 1 & NR & 5 \\
\hline Oettle & 1963 & 1 & African & 50 \\
\hline Duron & 1965 & 1 & NR & 59 \\
\hline Garrington & 1967 & 1 & Caucasian & 51 \\
\hline Oluwasanmi & 1969 & 1 & NR & 53 \\
\hline Halama & 1974 & 1 & $N R$ & 6 \\
\hline Alpert & 1978 & 1 & Caucasian & 7 \\
\hline Stoll & 1981 & 1 & African & 54 \\
\hline Scott & 1982 & 1 & $N R$ & 8 \\
\hline Wood & 1982 & 1 & NR & 52 \\
\hline Pehamberger & 1984 & 1 & Caucasian & 55 \\
\hline Luande & 1985 & 1 & $N R$ & 9 \\
\hline Kinnear & 1985 & 1 & NR & 56 \\
\hline Levine & 1992 & 1 & Caucasian & 10 \\
\hline Ihn & 1993 & 1 & Asian & 11 \\
\hline Casswell & 1989 & 1 & Caucasian & 57 \\
\hline Schulze & 1989 & $\begin{array}{l}1 \\
1\end{array}$ & $\begin{array}{l}\text { Caucasian } \\
\text { Hispanic }\end{array}$ & 58 \\
\hline Perry & 2001 & 1 & NR & 12 \\
\hline Asuquo & 2009 & 1 & African & 44 \\
\hline Mabula & 2012 & 1 & African & 46 \\
\hline
\end{tabular}

Note: The report by Ihn $\mathrm{H}$ et al. [11] describes a Japanese patient who is likely the same patient in the other report by $\mathrm{lhn} \mathrm{H}$ et al. [21].

Table 1: Twenty-five cases of malignant melanoma with oculocutaneous albinism in the English literature.

Among OCA patients, BCC and/or SCC cases were generally reported in Africans, likely due to intense exposure to ultraviolet light, insufficient medical access, and the non-prevalence of sunscreen application. We initially imagined that the numbers of BCC and/or SCC cases would be much higher among Japanese OCA patients because the incidence rates of BCC, SCC, and MM among skin cancer cases in the general Japanese population are $44 \%, 28 \%$, and $20 \%$, respectively [18-34]. However, we only identified 4 reported BCC cases and 6 reported SCC cases over a period of approximately 3 decades. This might be caused by 3 factors: first, the existence of unreported BCC and SCC cases in OCA patients; second, the under diagnosis of OCA because of skin and hair color compensation during adulthood; and third, the relative rarity of such cancer cases.

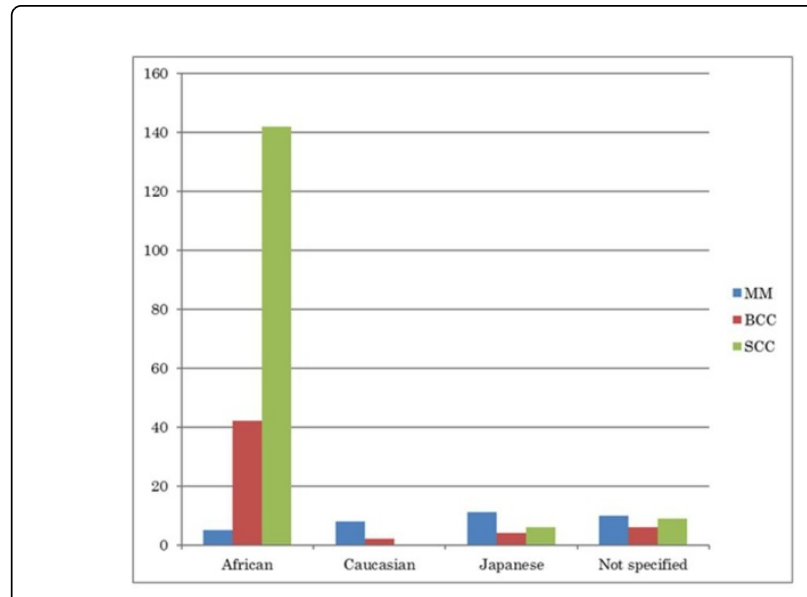

Figure 1: Numbers of MM, BCC, and SCC cases in African, Caucasian, and Japanese albino populations.

\section{Discussion}

In western Africa, most OCA patients are classified as having OCA type 2 (OCA2), which is caused by the same intragenic $P$ gene deletion mutation as the founder effect [35,36]. Japanese patients with mild OCA2 are frequently undiagnosed and are recognized as having noticeably pale skin and brown hair during infancy and normal pale skin and dark brown hair as adults [37]. We recently identified a polymorphism in the $\mathrm{P}$ gene, A481T, that is associated with skin color in the Japanese population.

\begin{tabular}{|l|l|l|l|l|}
\hline Author(s) & Year & No. of cases & Ethnicity & Ref. No. \\
\hline Cohen et al. & 1952 & 1 & African & 40 \\
\hline Higginson et al. & 1960 & 2 & African & 41 \\
\hline Oluwasanmi et al. & 1969 & 6 & NR & 53 \\
\hline Itayemi et al. & 1979 & 3 & African & 42 \\
\hline Kromberg et al. & 1989 & 2 & African & 39 \\
\hline Yakubu et al. & 1993 & 3 & African & 14 \\
\hline Colebunders et al. & 2004 & 1 & African & 15 \\
\hline Asuquo et al. & 2007 & 5 & African & 16 \\
\hline Adegbidi et al. & 2007 & 4 & African & 43 \\
\hline Asuquo et al. & 2009 & 1 & African & 44 \\
\hline Opara et al. & 2010 & 5 & African & 45 \\
\hline Baskurt et al. & 2011 & 2 & Caucasian & 17 \\
\hline Mabula et al. & 2012 & 15 & African & 46 \\
\hline
\end{tabular}

Table 2: Fifty cases of basal cell carcinoma with oculocutaneous albinism in the English literature.

Furthermore, we recently determined a relationship between a decrease-of-function polymorphism in the $\mathrm{P}$ gene and the occurrence of SCC, including actinic keratosis. Therefore, it is quite conceivable 
Citation: Yasumizu M, Nishigori N, Kawaguchi M, Takata T, Oiso N, et al. (2015) Malignant Skin Tumors in Patients with Oculocutaneous

Page 3 of 5

that many cases of SCC and BCC among Japanese albinos are unreported.

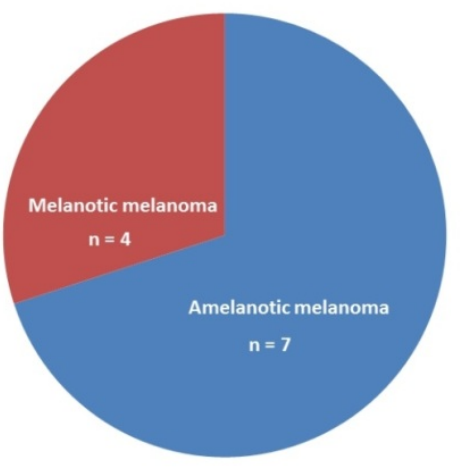

Figure 2: Among 11 malignant melanomas that developed in Japanese albinos, 7 were amelanotic melanomas, and the other 4 were melanotic melanomas.

In this study, we identified a trend in which the incidence of MM was higher in Japanese OCA patients than in African or Caucasian patients. The number of diagnosed Japanese OCA patients is approximately 5000, and MM occurred in 11 of these patients during a 35-year period. Therefore, the annual ratio of MM development in OCA patients is estimated to be approximately $1 / 16,000$, whereas that in the general population is estimated to be $1 / 100,000$ [38]. In fact, we recently identified an association between another decrease-offunction polymorphism in the $\mathrm{P}$ gene and the occurrence of $\mathrm{MM}$ [39-60].

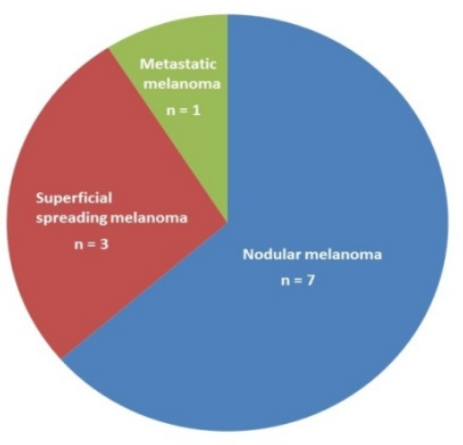

Figure 3: Among 11 malignant melanomas in Japanese albinos, 7 were nodular melanomas; 3 , superficial spreading melanomas; and 1 , metastatic melanoma.

In this report, it was first suggested that the incidence of amelanotic melanomas in Japanese albinos was $64 \%$ (7 out of 11; Figure 2). It is conceivable that amelanotic melanomas develop in patients with severe forms of albinism, for example, those with OCA type 1A. However, reports about the development of skin cancers in albinos usually do not have information about genetic analysis. The diagnosis of amelanotic melanoma is generally difficult via macroscopic examination. Therefore, any small skin tumor occurring in albinos should be carefully examined by board-certified dermatologists.

\begin{tabular}{|l|l|l|l|l|}
\hline Author(s) & Year & No. of cases & Ethnicity & Ref. No. \\
\hline Cohen et al. & 1952 & 1 & African & 40 \\
\hline Higginson et al. & 1960 & 2 & African & 41 \\
\hline Oluwasanmi et al. & 1969 & 6 & NR & 53 \\
\hline Itayemi et al. & 1979 & 3 & African & 42 \\
\hline Kromberg et al. & 1989 & 2 & African & 39 \\
\hline Yakubu et al. & 1993 & 3 & African & 14 \\
\hline Colebunders et al. & 2004 & 1 & African & 15 \\
\hline Asuquo et al. & 2007 & 5 & African & 16 \\
\hline Adegbidi et al. & 2007 & 4 & African & 43 \\
\hline Asuquo et al. & 2009 & 1 & African & 44 \\
\hline Opara et al. & 2010 & 5 & African & 45 \\
\hline Baskurt et al. & 2011 & 2 & Caucasian & 17 \\
\hline Mabula et al. & 2012 & 15 & African & 46 \\
\hline
\end{tabular}

Table 3: One-hundred fifty-one cases of squamous cell carcinoma with oculocutaneous albinism in the English literature.

\begin{tabular}{|l|l|l|l|l|l|l|}
\hline Author & Year & MM & BCC & SCC & No. of Cases & Ref. No. \\
\hline Yoshioka J & 1978 & + & - & - & 1 & 18 \\
\hline Ikeda S & 1981 & + & - & - & 1 & 19 \\
\hline Nagao H & 1991 & - & + & + & 2 & 20 \\
\hline Inn H & 1992 & + & - & - & 1 & 21 \\
\hline Inaba Y & 1992 & + & - & - & 1 & 22 \\
\hline Yuasa T & 1996 & + & - & - & 1 & 23 \\
\hline Hirose I & 1999 & - & + & + & 1 & 24 \\
\hline Hozumi H & 2002 & - & + & + & 1 & 25 \\
\hline Sakurane J & 2003 & + & - & - & 1 & 26 \\
\hline Sakai H & 2005 & + & - & - & 1 & 27 \\
\hline Obata M & 2005 & - & - & + & 1 & 28 \\
\hline Tsuji T & 2011 & + & + & Bowen & 1 & 29 \\
\hline Inazuka Y & 2012 & + & - & - & 1 & 30 \\
\hline Minagawa T & 2012 & - & - & + & 1 & 31 \\
\hline Fukai T & 2013 & + & - & - & 1 & 32 \\
\hline Aizawa A & 2013 & + & - & - & 1 & 33 \\
\hline
\end{tabular}

Table 4: Malignant skin tumors in patients with oculocutaneous albinism in the Japanese literature.

According to statistical reports of MM in Japan, the frequencies of acral lentiginous melanoma (ALM), superficial spreading melanoma (SSM), nodular melanoma (NM), and lentigo maligna melanoma 
(LMM) are $44 \%, 19 \%, 14 \%$, and $8 \%$, respectively.38 However, the frequencies of the above MM types among Japanese albinos were $0 \%$, $30 \%, 70 \%$, and $0 \%$, respectively.

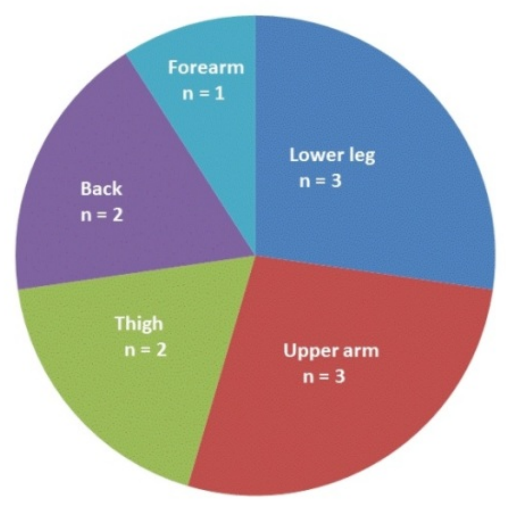

Figure 4: Of 11 malignant melanomas, 3 developed on the lower legs; 3 , upper arms; 2 , thighs; 2 , back; and 1 , forearm.

It is noteworthy that ALM, the most common MM type in the general Japanese population, has not been reported. The frequency of SSM, which is thought to be associated with intermittent severe sundamage, was higher among albino MMs, whereas the frequency of LMM, which is associated with chronic sun-exposure, was not observed. The most striking finding was that as many as $70 \%$ of albino MM cases were classified as NMs (Figure3). The cause of the high prevalence of NM among Japanese albinos might also be related to intermittent severe sun-damage and the consequent oxidative stress; however, this remains to be examined in the future.

\begin{tabular}{|l|l|l|l|l|l|l|l|}
\hline Author & Year & Amelanotic & Location & Type & Sex & Age & $\begin{array}{l}\text { Ref. } \\
\text { No. }\end{array}$ \\
\hline Yoshioka & 1978 & No & Lower leg & NM & F & 32 & 18 \\
\hline Ikeda & 1981 & No & Lower leg & NM & F & 30 & 19 \\
\hline Ihn & 1992 & No & Forearm & SSM & M & 58 & 21 \\
\hline Inaba & 1992 & Yes & Back & NM & F & 45 & 22 \\
\hline Yuasa & 1996 & Yes & Upper arm & NM & M & 64 & 23 \\
\hline Sakurane & 2003 & Yes & Upper arm & NM & F & 68 & 26 \\
\hline Sakai & 2005 & Yes & Lower leg & SSM & F & 70 & 27 \\
\hline Tsuji & 2011 & No & Back & SSM & F & 71 & 29 \\
\hline Inatsuka & 2012 & Yes & Upper arm & Meta & F & 66 & 30 \\
\hline Fukai & 2013 & Yes & Thigh & NM & M & 44 & 32 \\
\hline Aizawa & 203 & Yes & Thigh & NM & F & 56 & 33 \\
\hline
\end{tabular}

Table 5: Malignant melanoma in Japanese patients with oculocutaneous albinism.

It is important to note that MM occurred on the upper arms in 3 Japanese OCA patients and on the thighs in 2 patients because these regions are considered somewhat "blind" areas when applying sunscreen agents (Figure 4). Patients with OCA are advised to apply sunscreen agents to all sun-exposed areas, including the upper arms and thighs. Gene mutation analyses were not performed in any of the reports of albino MMs. The accumulation of such data is certain to be useful with respect to sun-protection protocols for albinos.

\section{References}

1. Lookingbill DP, Lookingbill GL, Leppard B (1995) Actinic damage and skin cancer in albinos in northern Tanzania: findings in 164 patients enrolled in an outreach skin care program. J Am Acad Dermatol 32: 653-658.

2. Gandini S, Sera F, Cattaruzza MS, Pasquini P, Picconi O, et al. (2005) Meta-analysis of risk factors for cutaneous melanoma: II. Sun exposure. Eur J Cancer 41: 45-60.

3. Curtin JA, Fridlyand J, Kageshita T, Patel HN, Busam KJ, et al. (2005) Distinct sets of genetic alterations in melanoma. N Engl J Med 353: 2135-2147.

4. Pleasance ED, Cheetham RK, Stephens PJ, McBride DJ, Humphray SJ, et al. (2010) A comprehensive catalogue of somatic mutations from a human cancer genome. Nature 463: 191-196.

5. Kennedy BJ, Zelickson AS (1963) Melanoma in an Albino. JAMA 186: 839-841.

6. Halama J, Szeigole M (1974) Casuistics of malignant melanoma in albinos. Strahlenther Onkol 147: 136-138.

7. Alpert LI, Damjanov I (1978) Malignant melanoma in an albino: diagnosis supported by ultrastructure. Mt Sinai J Med 45: 447-450.

8. Scott MJ Jr, Giacobetti R, Zugerman C (1982) Malignant melanoma with oculocutaneous albinism. J Am Acad Dermatol 7: 684-685.

9. Luande J, Henschke CI, Mohammed N (1985) The Tanzanian human albino skin. Natural history. Cancer 55: 1823-1828.

10. Levine EA, Ronan SG, Shirali SS, Das Gupta TK (1992) Malignant melanoma in a child with oculocutaneous albinism. J Surg Oncol 51: $138-142$.

11. Ihn H, Nakamura K, Abe M, Furue M, Takehara K, et al. (1993) Amelanotic metastatic melanoma in a patient with oculocutaneous albinism. J Am Acad Dermatol 28: 895-900.

12. Perry PK, Silverberg NB (2001) Cutaneous malignancy in albinism. Cutis 67: 427-430.

13. Datubo-Brown DD1 (1991) Primary malignant skin tumors in Nigerians. J Natl Med Assoc 83: 345-348.

14. Yakubu A, Mabogunje OA (1993) Skin cancer in African albinos. Acta Oncol 32: 621-622

15. Colebunders R1, Bottieau E, Van den Brande J, Colpaert C, Van Marck E (2004) Merkel cell carcinoma and multiple basal cell carcinoma in an African albino woman with HIV infection. HIV Med 5: 452-454.

16. Asuquo ME, Agweye P, Ugare G, Ebughe G (2007) Basal cell carcinoma in five albino Africans from the south-eastern equatorial rain forest of Nigeria. Int J Dermatol 46: 754-756.

17. BaÅŸkurt H, Celik E, YeÅŸiladali G, Tercan M (2011) Importance of hereditary factors in synchronous development of Basal cell carcinoma in two albino brothers: case report. Ann Plast Surg 66: 640-642.

18. Yoshioka J, Kitamura W (1978) Akuseishuyou wo gappeisita oculocutaneous albinism no 1 rei. Rinshohifuka 32: 355-364.

19. Ikeda S, Makita A, Tajima K (1981) Zenshinsei hakuhisou (Shirako) ni mirareta kokusi oyobi akusei kokushokushu. Iyakunomon 21: 81-85

20. Nagao H, Arakawa K, Arata J (1991) Hifu-akuseishuyo wo shoujita zensinnsei-hakuhishou no 2 rei. Skin cancer 6: 90-94.

21. Ihn H, Nakamura K, Abe M, et al (1992) Tasai-na gappeishou wo tomonatta gan-hifu-hakuhishou-kanja ni mirareta akusei-kokushokushu no 1 rei. Skin cancer 7: 158-162.

22. Inaba Y. Mihara I (1992) Gan-hifuhakuhishou ni hasseisita akuseikokushokushu. Rinshohifuka 46: 129-135. 
23. Yuasa T, et al. (1996) Hakushihou ni gappeisita akusei-kokushokushu. Rinshouhifuka 50: 926-929.

24. Hirose I, Akaba N, Shinokawa Y, Kaji T (1999) Zenshinsei-hakuhishou ni shoujita tahatsusei-hifu-akuseishuyu-rei. Nihon-keiseigeka-gakkai-zassh 19: 711-712.

25. Hozumi H, et al. (2002) Chirosinaze-inseikata-hakuhishoukannja no migikasi ni shoujita henpeijouhi-gan to kiteisaibou-gan. Nishinihonhifuka 64: 443-436.

26. Sakurane J, et al. (2003) Albinism ni tomonatta amelanotic melanoma no 1 rei. Nihon-hifukagakkai-zasshi 113: 197-198.

27. Sakai H, Shirai Y, Terao M, Shrabe H (2005) Tahatsuseinikkoukakukashou wo yusuru hakuhishoukanja ni shoujita akuseikokushokushu. Hifunokagaku 4: 325-326.

28. Obata M (2005) Kourei-hakushishou kannja ni okeru sigaisen hatsugan no 1 rei. Nihonhifukagakkaizasshi 115: 907-909.

29. Tsuji T, et al. (2011) Hifu-akuseishuyou wo tahatsu-shita gan-hifuhakuhishou no 1 rei. Nishinihonhifuka 73: 319-320.

30. Inatsuka Y, Nagata K, Hatano Y, Okayama N (2012) Hakuhishou ni shoujita akuseikokushokushu no 1 rei. Nishinihonhifuka 74: 100-102.

31. Minagawa T, Kaneko T, Matsuzaki Y, Nakano H, Sawamura D, et al. (2012) Yukyokusaibougan to Bowen-byou wo tomonatta gan-hifuhakuhishou no 1 rei. Nihonhifukagakkaizasshi 122: 637 -638.

32. Fukai T, Hirasawa Y, Hasegawa T, Ikeda S (2013) Gan-hifu-hakuhishoukanja ni hasshou sita akuseikokushokushu no 1 rei Nihonrinshouhifukaikaizasshi 30: 238-239.

33. Aizawa A, Asano Y, Matsuyama A, et al (2013) Gan-hifu-hakuhishoukanja ni hasseisita akuseikokushokushu no 1 rei. Nihonhifukagakkaizassi 123: $163-164$

34. Ishihara K (2007) Akusei shuyou no toukei kako. Skin Cancer 22: 209-216.

35. Durham-Pierre D, Gardner JM, Nakatsu Y, King RA, Francke U, et al. (1994) African origin of an intragenic deletion of the human $P$ gene in tyrosinase positive oculocutaneous albinism. Nat Genet 7: 176-179.

36. Spritz RA, Fukai K, Holmes SA, Luande J (1995) Frequent intragenic deletion of the $\mathrm{P}$ gene in Tanzanian patients with type II oculocutaneous albinism (OCA2). Am J Hum Genet 56: 1320-1323.

37. Abe Y, Tamiya G, Nakamura T, Hozumi Y, Suzuki T (2013) Association of melanogenesis genes with skin color variation among Japanese females. J Dermatol Sci 69: 167-172.

38. Fujisawa Y, Otsuka F, Yamamoto A, Yamazaki N, Saida T, et al. (2012) Statistics of melanoma in Japan: Analysis of a 2006-2007 nation-wide survey and a 2005-2010 follow-up survey. Skin Cancer 27: 195-204.

39. Kromberg JG, Castle D, Zwane EM, Jenkins T (1989) Albinism and skin cancer in Southern Africa. Clin Genet 36: 43-52.

40. Cohen L, Shapiro MP, Keen P, Henning AJ (1952) Malignant disease in the Transvaal. I. Cancer of the skin; first statistical report from the Radiation Therapy Department of the Johannesburg group of hospitals. S Afr Med J 26: 932-939.

41. Higginson J, Oettle AG (1960) Cancer incidence in the Bantu and "Cape Colored" races of South Africa: report of a cancer survey in the Transvaal (1953-55). J Natl Cancer Inst 24: 589-671.
42. Itayemi SO, Abioye AA, Ogan O, Daramola JO, Oluwasanmi JO (1979) Aggressive basal cell carcinoma in Nigerians. Br J Dermatol 101: 465-468.

43. Adegbidi H, Yedomon H, Atadokpede F, Balley-Pognon MC, do AngoPadonou F (2007) Skin cancers at the National University Hospital of Cotonou from 1985 to 2004. Int J Dermatol 46 Suppl 1:26-29.

44. Asuquo ME, Ngim O, Ebughe G, Bassey EE (2009) Skin cancers amongst four Nigerian albinos. Int J Dermatol 48: 636-638.

45. Opara KO, Jiburum BC (2010) Skin cancers in albinos in a teaching Hospital in eastern Nigeria - presentation and challenges of care. World J Surg Oncol 8: 73.

46. Mabula JB, Chalya PL, Mchembe MD, Jaka H, Giiti G, et al. (2012) Skin cancers among Albinos at a University teaching hospital in Northwestern Tanzania: a retrospective review of 64 cases. BMC Dermatol 12: 5 .

47. Bhende YM (1952) Malignant amelanotic melanoma of skin in albino. Indian J Med Sci 6: 755-759.

48. Young TE (1957) Malignant melanoma in an albino; report of a case. AMA Arch Pathol 64: 186-191.

49. Leonardi R, Grasso S (1958) [Melanoblastoma in albino; histological findings]. Minerva Dermatol 33: 24-26.

50. Oettle AG (1963) "Skin cancer in Africa". Conference on Biology of Cutaneous Cancer.

51. Garrington GE, Scofield HH, Cornyn J, Lacy GR Jr (1967) Intraoral malignant melanoma in a human albino. Oral Surg Oral Med Oral Pathol 24: 224-230.

52. Wood C, Graham D, Willsen J, Strefling A (1982) Albinism and amelanotic melanoma: occurrence in a child with positive test results for tyrosinase. Arch Dermatol 118: 283-284.

53. Oluwasanmi JO, Williams AO, Alli AF (1969) Superficial cancer in Nigeria. Br J Cancer 23: 714-728.

54. Stoll DB, Ruschak P, Kauh Y, Martin J, Luscombe H (1981) Lentigo maligna in a woman with oculocutaneous albinism. Arch Dermatol 117: 360-361.

55. Pehamberger $\mathrm{H}$, Hönigsmann $\mathrm{H}$, Wolff $\mathrm{K}$ (1984) Dysplastic nevus syndrome with multiple primary amelanotic melanomas in oculocutaneous albinism. J Am Acad Dermatol 11: 731-735.

56. Kinnear PE, Tuddenham EG (1985) Albinism with haemorrhagic diathesis: Hermansky-Pudlak syndrome. Br J Ophthalmol 69: 904-908.

57. Casswell AG, McCartney AC, Hungerford JL (1989) Choroidal malignant melanoma in an albino. Br J Ophthalmol 73: 840-845.

58. Schulze KE, Rapini RP, Duvic M (1989) Malignant melanoma in oculocutaneous albinism. Arch Dermatol 125: 1583-1586.

59. Durón RA (1965) [Malignant melanoma in albinos]. Rev Med Hondur 33: $149-156$

60. Yoshizawa J, Abe Y, Oiso N, Fukai K, Hozumi Y, et al. (2014) Variants in melanogenesis-related genes associate with skin cancer risk among Japanese populations. J Dermatol 41: 296-302. 